\title{
Language Policy and Medium of Instruction Issue in Pakistan
}

\author{
Ali AMMAR \\ Institute of Social Sciences, BZU, Multan \\ Pakistan \\ aracademy123@gmail.com
}

\author{
Ali FAWAD \\ Quaid-e-Azam University Islamabad \\ Pakistan \\ aracademy@yahoo.com
}

\author{
Naveen ALI \\ NUML University Multan Campus \\ Pakistan \\ naveenali731@gmail.com \\ Khamsa QASIM \\ GCU, Faislabad \\ Pakistan \\ 120071@students.au.edu.pk
}

\begin{abstract}
The issue of language in Pakistan is not just related to linguistics. It has far more implications for cultural, economic, political, and social dimensions of Pakistani society. The current paper studies the latest language policy of Pakistan and its implications for local languages. It then relates to the formation and implementation of a (certain steps) feasible language policy to root out the conflicts and ethnic clashes from time to time in the country, and discusses ways to survive the language shock of majority of students in Pakistan, who are taught English as compulsory subject up to 14 years of education despite the puzzling phenomenon of cultural aversive attitudes towards English language by the masses. The employed teaching methods and curriculum in the institutions of Pakistan, for decades, have only been successful in maintaining the gap between the privileged English speaking people and the hardcore anti-English sentiments. In this battle for linguisticidentity crisis and supremacy, a lot of national talent has been wasted. This paper briefly reexplores the situation of languages in the country on the first step, and then it moves on to focus on the national policy, its flaws, and it possible ways out by bringing in examples from Chinese and Indian Language Policies.
\end{abstract}

Keywords: language policy; ethnic; aversive attitudes; linguistic-identity; anti-English sentiments

\section{Povzetek}

Dileme jezika $v$ Pakistanu niso povezane samo z jezikoslovjem. Njihove posledice je čutiti na kulturnem, ekonomskem, političnem in socialnem področju pakistanske družbe. Članek natančno pregleda trenutno jezikovno politiko v Pakistanu in njen vpliv na lokalne jezike. Naveže se na oblikovanje in uvedbo tistega dela jezikovne politike, ki bi kar najbolj izkoreninil med-etnične konflikte. Obenem se dotakne obveznega 14-letnega učenja angleščine $v$ šolah, ki se otepa splošnega ljudskega odpora, saj naj bi le povečeval razlike med priviligiranim slojem angleškogovorečih in preostalimi. $\mathrm{V}$ boju za jezikovno identiteto in prevlado je bilo precej izgubljenega. Članek tako prevetri jezikovno situacijo in razmišlja o nacionalni jezikovni politiki ter o jezikovnih politikah na Kitajskem in v Indiji, katerih ideje bi bilo moč privzeti.

Ključne besede: jezikovna politika; etničnost; averzivni pogled; jezikovna identiteta; proti-angleška čustva 


\section{Introduction}

Socioeconomic and political considerations are taken into account while choosing languages and giving them official, administrative or semi-official status to be used in the fields of education, administration and so on (Agnihotri et. al, 2006). Like all multilingual countries, Pakistan has also been facing challenges in this regard. Yet, her case is more complex owing to the religious pressures and demands which cannot be put aside due to the fact that Islam, the religion of majority in the country, cannot be dissociated from any aspect of life.

The revised manual of Education Policy, uploaded on August 1, 2009, formulated with the collaborative efforts of the relevant government and non-government agencies including universities, has very little to offer for the resolution of language issues infested in Pakistan since her inception in 1947. In order to understand the language issues of the country, first we would draw our attention to the current situation of languages in Pakistan. There are six major and 58 minor languages in Pakistan (Rahman 2002). The largest ethnic group is Punjabi around $44.15 \%$ (Census 2001); while Urdu, besides being the most widely understood, spoken and official language, remains at 7.57\% (Census 2001); and English is used for administrative and academic purposes based on the principle of necessity to a very limited level (see NORRIC Report 2006). Other major spoken languages of Pakistan include Sindhi at $14.10 \%$, Pashto at $15.27 \%$, Baloch $3.57 \%$, and Siraiki at $10.53 \%$ (Census 2001). Grimes (2000) reports that more than 105 million people use Urdu as second language. In 2009, government of Pakistan made English as medium of instruction at school level from 1 to 12 years of education but still there are many problems in its implementation due to lack of teachers' skills, students' attitudes, socio-cultural conditions, ethnic conflicts, and political concerns (see PEELI Report 2013). According to the findings of PEELI report (2013), 56\% of government sector school teachers' scored very low in computer based Aptis language testing system, while $62 \%$ of private school teachers' scored very low. These results mean that the teachers did not have basic understanding of English sentence structure (see PEELI Report 2013). One of the major reasons for this poor performance may be that around $65 \%$ to $70 \%$ of the population lives in rural area where the situation English as medium of instruction is even worse and most of the times teachers have been observed teaching in Urdu or local regional language i.e. Siraiki, Punjabi, Balochi, Pashto, or Sindhi (see NORRIC Report 2006). It is a significant marker of failure of Pakistan's Language policies, a country which has been wrought with the failed language policies since its inception (Rahman 2002).

\section{Language Policy of Pakistan}

In its earlier meetings, the Advisory board of Education had decided that at primary level the medium of instruction would be mother tongue that for the majority of population of Pakistan is either Punjabi, Siraiki, Sindhi, Urdu, or Pashto (ABD, 1948), 
but due to colonial influences and emotive value of Urdu especially in the Hindi-Urdu controversy, Urdu remained the official medium of instruction in most of the institutions of Pakistan (Rahman, 1995). But the elitist ideology and status attached to English by the ruling class kept English at the dominating level, and Urdu started to recede and began to be associated with the concepts of religious fundamentalism and conventionalism, a phenomenon most abhorred by the dominant colonized offspring of ruling elite (Brass, 1991). Yet again, Pakistan's most popular and active constitution of 1973 states that Urdu would be national language and further necessary arrangements would be made in the next fifteen years for Urdu to be used officially and for other purposes (Article 251). This means that English would be replaced by Urdu at official and national level. But like most of the policies, it also doomed to the dust of papers. Rahman (2002) contends that the basic reason is the inclination of the ruling elite towards English for modernization, colonial asset, thirst for association with western culture and globalization. With the long history of Hindi-Urdu controversy, as both of these languages were set at opposing battlegrounds on religious and ideological platform, almost same happened in the case of English and Urdu. Besides the majority sentimental and religious concerns in the favour of Urdu as medium of instruction and administration (or so propagated), English language could not be replaced due to its value at international level in economy, politics and academics.

This polarized state of Urdu-English controversy even deepens when the active constitution of Pakistan of 1973 (article 33) states that education policy should be according to the Islamic ideology with Islamic studies to be the code of life in all educational levels (NEP, 1998-2010). In the backdrop of Pakistani educational institutions in which Madressahs vs English Medium Schools, Government Institutions vs Private English Schools, hybrid low status private schools vs elite private schools, Cambridge system of education vs Government Higher and Secondary Schools (NORRIC Report, 2006), the conflicts have escalated from the level of differences in languages to that of ethnic and religious identities and ideologies. Millions of talented Pakistani students thus remain in a state of constant confusion and tension with mixed aversive and acceptance attitudes towards English language. This situation also causes very low performance in language learning. English language learning for majority of students in Pakistan is more a tense and troublesome activity than a pleasant exercise. In this condition, a uniform language policy is a far reaching dream for Pakistan.

In the revised National Education Policy manifesto of Federal Government of Pakistan (2009), the challenge to carry forward the cultural asset i.e. Urdu language and literature, and also to be able to meet the growing needs of modernism and economic well being i.e. learning of English, has been very aptly identified. The solution offered that manifesto is that, 'the curriculum from Class I onward shall include English (as a subject), Urdu, one regional language, mathematics along with an integrated subject' (NEP, 2009). Mathematics and Sciences would be taught in Urdu or English language for five years and after that these would only be in English 
language (NEP, 2009). Such policy statements and resolutions make it clear that English is going to remain not only the part of curriculum in Pakistan but also as the medium of instruction. Such decision by the state to use English as the language of instruction is actually language allocation (Gorman, 1973). Hence in Pakistan, there is English backed by the state and the powerful elite versus local languages supported by majority ethnic groups, and in the middle is the young hungry talent of this developing state crunched under the innumerable geo-political, social, economic and psychological pressures from inside and abroad.

\section{What has this policy to offer?}

Kloss (1969) suggests that language planning has to focus on three dimensions i.e. status, acquisition, and corpus planning. National Education Policy (2009) has something to offer about the status planning of English and Urdu when it states that English and Urdu would both be taught at primary level and English would be medium of instruction from class 5 onwards. But this policy lacks completely in the spheres of acquisition and corpus planning, which add up to the problems of students as well as teachers.

Regarding the status of languages, this policy seems to be developed without considerations of the socio-cultural needs of one important element of stake holders i.e. powerful ethnic groups and on the other hand it is aligned with the ideals of powerful elite. In papers, this policy is going to restrict major regional languages of Pakistan as a subject to be studied in curriculum up to a limited level, and implement English language at broader level up to advanced studies. This situation creates reservations by the ethnic groups and gives rise to mass gatherings for their shows of power from time to time that have the capacity to erupt at any time into ethnic violence of which Pakistan has a long complex history. Isn't it like keeping a time bomb in the pocket and shutting eyes to the realities of explosions? It is more like a colonized state of affairs on the part of the policy makers and the powerful elite.

Least attention has been paid to the acquisition of language which is related to teaching methodologies and language learning (Cooper 1989). Yet, the language policy of Pakistan favours the language shift, which is the shift from using one language to another and normally from less powerful to the powerful (Rahman, 1996). It also implies the idea of shifting at the expense of already prevalent language. In the case of Pakistan, the sacrificed languages are Urdu and other major regional languages. To achieve this objective, English language communication courses are a compulsory part of university level education in Pakistan as well. However, the teaching methodologies are not defined clearly. It is left to the choice of teachers who normally have no formal instructions in teaching methodologies and in using language labs. Therefore, the graph of communicative competence in English remains very low (see PEELI Report 2006), and the conflict in the teachers and learners about the 
utilization and learning of English vs other languages remains a constant source of tension and anxiety in general.

National Education Policy (2009) has nothing to say about the corpus planning. Corpus planning is related to the development and change in certain language of policy choice (Fishman, 1977). The current practice is that of importing corpus from foreign books in the form of short stories, plays, essays and poetry written by the foreign writers. Mostly, in Pakistani institutions, the corpus provided by the westerners, typically that of English, is copied and arranged in the text books of Pakistani institutions at all levels. Many studies show that the cultural and social attitudes of learners, after learning a second language, change to a great extent (Christensen, 2004; Dirim \& Auer, 2004; Jaspers, 2007; Juffermans, 2010; Keim, 2007). In the 'English Language class' the students are normally conscious of where they are sitting and what they are studying. This consciousness develops certain attitudes among the learners associated with the features of the English (Jorgenson, 2010). The prevalence of English in the same manner at such a massive scale in Pakistan also bears its massive impact on the attitudes of Pakistani students. This denotes 'sociocultural' changes as observed in many studies conducted in Pakistan (Rahman, 1995).

Another important aspect of learning the particularly borrowed corpus by the English is that of 'privilege'. The learners of English language are normally given more privilege than those without it in Pakistan and are considered among the literate learned segment of society. Hence, the more anglicized the learner, the more privilege, he is going to get in society (Jorgensen, 2010). For Pakistani society, this issue of privilege is giving rise to an academic-class-categorization that is pushing the non-native like English speakers or low competence level students already in the back seats of learning. This divide among students starts from the primary level and continues up to university level in Pakistan.

Besides the assertion on the preservation and propagation on the cultural asset that echoes in the constitution of 1973 (article 33), the cultural input through corpus is going to be reduced to the subjects of Urdu and Islamic studies up to a certain level of classes. These also have very limited economic and power associated promises in the career planning of students in Pakistan. It is like putting the culture at stake which was the ideological basis in the making of this country, and also being at a collision with the ethnic groups.

Mathematics and Science students in Pakistan normally go for engineering and medical sciences which is the guarantee of prosperity at economic and social level, a modern phenomenon and quite at hype in the progressing states with Pakistan being no exception. Hunger does not need much of a culture than bread. For masses, the drive for bread surpasses all other drives. Hence, the privilege that English is going to enjoy because of teaching these subjects in English (NEP, 2009), is never going to be that of other languages of people of Pakistan. This Anglo-centric ambitious policy is going to heighten the ethnic conflicts already present in various other forms in the country like tribalism, sectarianism, religious intolerance and provincialism. The cost 
of giving English a supremacy over other languages is going to be high in terms of socio-political unrest and culture slaughter.

With national education policy lacking in acquisition and corpus planning, issues of academic-class divisions, social and economic privileges, wastage of young energetic talent, ethnic conflicts, and confusion in the vision of education are certain grave issues that need serious attention. In the coming lines, the case of china and India, as neighbouring countries that share some historical commonalities with respect to independence times and ethnic issues, is discussed, and a viable solution is also presented for specific case of Pakistan.

\section{The Case of China and India}

The linguistic issues of China and India are briefly presented here because of some very important reasons. Both countries are nighbours, with India having lots of cultural similarities with Pakistan. These countries have almost the same independence years. Both are multilingual and ethnic like Pakistan. And all have started their journey from being developing countries. According to Constitution of Pakistan Article 2, Islam would be the state religion. Islam has this inherent ability and obligation to be the part and parcel of all activities ranging from individual to social, constitutional to ethnic and so on. This aspect has been very influential throughout Pakistani history, more so in the case of choosing languages for Pakistan. Therefore, in the next heading, while discussing recommendations for linguistic policy, a great care and thought has also been given to it.

English has been gaining lot of importance in China in the last quarter century (Hu, 2010), and it has also been associated with the nation's progress and modernization (Cortazzi \& Jin, 1996). The increase in learning English language in the new millennium can be realized by the research of Jiang (2003) who states that parents are even pressuring their children to learn and speak English. Around 200-300 million people study English in China at any phase of their education (Zhao and Campbell, 1995). Though, officially foreign languages are considered as belonging to different cultures and are not made part of official and administrative purposes, yet English language learning is constantly increasing (Ross, 1993). The reasons for not making English as the official language of China are cultural and national for which Chinese are very specific. However, realizing the need of English language, various language teaching methods have been adopted in china. Grammar-translation methods and audiolingualism got lot of support but the communicative competence of the learners remained very low $(\mathrm{Hu}, 2001)$. Later on, communicative language teaching (CLT) method was adopted to address the issue of low level of English language competence (Hu, 2010). There have been lot of debates by researchers on the need to adopt CLT in China (e.g. Anderson, 1991; Burnaby \& Sun, 1989; Li, 1984; Rao, 1996; Wang, 2001). Yet CLT failed to yield required results in China due to some conflicts with Chinese culture of learning (Hu, 2010). CLT focuses on interaction with 
students by encouraging students to focus on the communicative functions of language (Brown, 2001; Widdowson, 1990), whereas, Chinese culture is greatly influenced by Confucianism (Biggs, 1996; Lee, 1996; Scollon, 1999), that lays great stress on respect for knowledge, development of not only academic aspects but also of the moral qualities of students (Guo, 2001; Llasera, 1987; Scollon, 1999) having an extremely respectable relationship with the teachers. These aspects of Chinese culture of learning are quite contradictory to western culture of learning where there are free and open discussions among the students and teachers with different respect levels. Therefore, CLT has not been a very successful language teaching method in China (Rao, 2002). This means that cultural and ideological aspects of a society can be a major factor in teaching and learning of languages.

Owing to the linguistic diversity in India, three languages policy was incorporated in National Education Policy of 1986 recommended by the National commission on Education 1964-1966 (Meganathan, 2011). There has also been massive researches on the choice and promotion of languages at national and private level in India. According to the policy of 1986, the three languages, to be adopted in India, included one regional language, Hindi or any other area language, and English or any modern European language (GOI, 1962, p. 67). According to the survey of $2002,84.86 \%$ of the primary education is conducted on the basis of three language formula with $13.26 \%$ of secondary education is in English as first language and 33.08\% in Hindi as first language. However, use of English as second language is $54.12 \%$ at secondary level education in India (Survey, 2002). Hindi and English are the most frequently used languages in the 32 states of India (Meganathan, 2011). As the Education Commission (1966) had debated that English would continue to have higher status because of its usage at university and official level, the above statistics regarding English as first and second language re-emphasize the same speculation. With clarity in incorporating languages of Indian culture and English language in the mainstream educational system in India, it has been a great success. The developments in the indigenous languages have also been going along especially in the case of Hindi that has resulted in the increase in "prestige, wealth, power, electronic technology, and presence in education system" (Crystal, 2000). Moreover, Indian propagation and promotion of nationalism on media has also been a major factor in the development of indigenous languages. This country has not suffered so many riots due to language issues as compared to Pakistan. The linguistic diversity, media propagation for English language and less intense historical and cultural bias towards English has paved the way for the implementation of three languages policy. The roots of learning English without biased approach also date back to pre-partition times for Indians.

\section{What to Do?}

On the contrary, in the case of Pakistan, the cultural demands are strictly more prevalent which require proper language planning and implementation in order to come out of the confusion and the downward academic trend of youth. It is necessary 
that the responsible and concerned personnel should take certain emergency steps in order to resolve this issue.

The primary action required for language policy of Pakistan is to clarify the choice of medium instruction and the status of official and administrative language. For this there is need of a three languages formula. English and Urdu need to go side by side as compulsory subjects from class 1 to masters, with a regional language as compulsory at primary and secondary level (up to $10^{\text {th }}$ grade) . Clearly defined status of languages needs to be ensured for the concern of the people of Pakistan. Prior to implementation of three languages formula, it is impertinent to conduct a large scale survey regarding the attitudes and opinions of the concerned stakeholders, including responses from variety of people of Pakistan from all provinces. The voice of the people, thus heard and prioritized, would make the policy implementation task much easier and practical.

In order to tone down the cultural pressures, Pakistan needs corpus planning. The intelligentsia and linguists need to devise syllabi of all classes by adding maximum cultural contents in both English and Urdu text books. The object of learning English, particularly, has to be functional. Mastering English language skills would be easier for the students when the material and course contents are culturally relevant.

A governmental department of translation needs to be set up whose job should be to translate all the latest and valid researches from foreign languages into Urdu and other significant regional languages. This would serve as the lifeline for Urdu and other regional languages and would be pivotal in keeping these languages alive. Establishment of digital libraries, plagiarism checks and ready research materials would further reinvigorate Pakistani students to develop themselves further in this language.

For English teaching, culture-centered teaching methodologies need to be developed owing to the needs of the masses which account for rural population about $65 \%$ of the total population. The focus should be on the skills i.e. reading, writing, listening and speaking. Writing and speaking skills need to be focused more as these are related to linguistic output. The exams also need to be oral as well as written with special focus on unseen questions in order to avoid rote learning. Not all grammatical rules are needed at the initial level to be taught, as is the case in Pakistan. This would require more effort from the teachers as well as from students. Moreover, traditional method of English teaching, syllabus, and course contents has already failed and caused wastage of talent for many years.

Development of teachers is a very important aspect that needs lot of improvement. In Pakistan teachers are selected on the basis of qualifications and exams/interviews. This is not a sufficient criteria to select a teacher. Teachers should be selected initially for a certain period of time in order to evaluate them if they are fir for teaching, primarily for a certain period whose evaluation should be conducted on regular basis. At the end of probationary term, they should be selected or rejected. In the selection of teachers, experienced teachers, administrators, and 
members of community should also be involved. After their selection, there should be regular exams for promotions and development of teachers.

\section{Conclusion}

The issue of medium of instruction has become a severe challenge for Pakistan that needs to be addressed on emergency basis to put the country on trek of development. Serious steps are required in status planning of all the languages to be selected for Pakistan. Corpus planning should be done carefully that should consist of maximum cultural contents, for Pakistan, being an ideological state cannot move on while ignoring the cultural and religious aspects. Language acquisition planning, in essence, needs to be done for the betterment of teachers as well as learners to learn languages speedily and easily bearing in mind the available resources and environment of Pakistani institutions. The voice of the concerned stakeholders has a special place in this regard as, time and again, there are strong ethnic protests owing to the westernization policies from different quarters of the country. A large scale survey in this regard would be mandatory for implementation of clear language formula. A well defined language policy is in the best interest of the country in many respects primarily for ending the wastage of talent due to language barriers, subsiding ethnic conflicts in Pakistan, coming out of the much debated issues of hybridization and confusion, and for carrying out researches in various field of knowledge for sustainability and development of the country.

\section{References}

Abbas, S. (1993). The Power of English in Pakistan. World Englishes 12 (2), 147-156.

Adams, C. (1978). In Language Problems \& Language Planning, ed. Moshe Nahir 8, 3 (February), 310-322.

Agnihotri, R. et. al. (2006). Position Paper. National Focus Group on Teaching of Indian Langauges. New Delhi: NCERT

Alavi, H. (1972). The State in Post-Colonial Societies -- Pakistan and Bangladesh. New Left Review 74 (July-August), 59-81.

Alam, S. (1991). Language as Political Articulation. Journal of Contemporary Asia 21 (4), 469- 487.

Alisjahbana, T. S. (1968). Some Planning in the Indonesian-Malay Language'. In Can Language be Planned? Sociolinguistic Theory and Practice for Developing Nations, eds Rubin \& Jernudd, 179-187. Honolulu: The University of Hawaii Press.

Amin, T. (1988). Ethno-National Movements of Pakistan: Domestic and International Factors. Islamabad: Institute of Policy Studies. 
Anderson, B. (1991). Imagined Communities: Reflections on the Origin and Spread of Nationalism. London: Verso.

Auer, P. (Ed.). (1998). Code-switching in conversation. Language, interaction and identity. London: Routledge.

Banuri, T. (1990). Modernization and its Discontents. In Dominating Knowledge: Development, Culture, and Resistance, ed. Frederique Apffel Marglin and Stephen A. Marglin, 73-101. New York: Clarendon Press.

Bhatt, R. M. (1992). Sociolinguistic Area and Language Policies. In Dimensions of Sociolinguistics in South Asia: Papers in Memory of Gerald Kelly, eds. Edward C. Dimock, et al., 47-69. Lahore: Vanguard Books; New Delhi: American Institute of Indian Studies.

Biggs, J.B. (1996b)Western misperceptions of the Confucian-heritage learning culture. In D.A. Watkins and J.B. Biggs (eds) The Chinese Learner: Cultural, Psychological and Contextual Influences (pp. 45-67).Hong Kong: CERC and ACER.

Brass, P. (1991). Ethnicity and Nationalism. New Delhi \& London: Sage Publications.

Brown, H.D. (2001) Teaching by Principles: An Interactive Approach to Language Pedagogy. New York: Longman.

Burnaby, B. and Sun, Y.L. (1989)Chinese teachers' views of Western language teaching: Context informs paradigms. TESOL Quarterly 23, 219-38.

Chaudhry, N. A. (1977). Development of Urdu as Official Language in the Punjab. Lahore: Government of the Punjab.

Christensen, M.V. (2004). Arabiske ord i dansk hos unge i multietniske omra ${ }^{\circ}$ der i $A^{\circ}$ rhus [Arabic words in Danish in adolescents from multiethnic areas in Aarhus]. In C.B. Dabelsteen \& J.S. Arnfast (Eds.), Taler de dansk? Aktuel forskning i dansk som fremmedsprog [Do you speak Language, Culture and Curriculum 69. Danish? Current research in Danish as a foreign language] (Københavnerstudier i tosprogethed bind 37, pp. 33-52). København: Københavns Universitet.

Cooper, R. L. (1989) Language Planning and Social Change. Cambridge: Cambridge University Press.

Cortazzi, M. \& Jin. L.X. (1996). Cultures of learning: Language classrooms in China. In Society and the language classroom, ed. H. Coleman, 169_206. Cambridge: Cambridge University Press.

Crystal, David. (2000). Language Death. Cambridge: Cambridge University Press.

Dirim, l'., \& Auer, P. (2004). Türkisch sprechen nicht nur die Türken. Über die Unschärfebeziehung zwischen Sprache und Ethnie in Deutschland [Not only the Turks are speaking Turkish. On the uncertain relation between language and ethnicity in Germany]. Berlin: De Gruyter. Edwards, John (ed). Linguistic Minorities, Policies and Pluralism. London: Academic Press.

Faridi, Q. (1977). Hebrew Language Planning and the Public. In Language Planning Processes, eds. Rubin et al., 151-156. The Hague: Mouton. 
Ferguson, C. A. and Das G. J. (1968). Language Problems of Developing Nations. New York: John Wiley \& Sons.

Fishman, J. A. (1974). Advances in Language Planning.The Hague: Mouton.

Geertz, G. (1963). The Integrative Revolution: Primordial Sentiments and Civil Politics in the New States. In Old Societies and New States: The Quest for Modernity in Asia and Africa, ed. Guido Geertz, G. New York: Free Press.

GOI (Government of India). (1962). Annual Report 1961-1962. New Delhi: Ministry of Education.

Gorman, T. P. (1973). 'Language Allocation and Language Planning in a Developing Nation'. In Language Planning: Current Issues and Research, ed. Joan Rubin and Roger Shuy, 72-82. Washington: Georgetown University Press.

Grimes, B. F. (ed). (2000). 'Pakistan'. In Ethnologue: Languages of the World. 14th Edition Dallas, Texas; Summer Institute of Linguistics. pp, 588-598.

Guo, Q.J. (2001) Zhongguo chuantong jiaoyu [Traditional Chinese education]. Retrieved July, 2001 from the World Wide Web: http://www.edu.cn/zhong_guo_jiao_yu_/ da_shi/index.php

Hallberg, D. G. (1992). Pashto, Waneci, Ormuri, Sociolinguistic Survey of Northern Pakistan. Vol. 4. Islamabad: National Institute of Pakistan Studies \& Summer Institute of Linguistics.

Harries. L. (1983). The Nationalisation of Swahili in Kenya. In Language Planning and Language Education, ed. Chris Kennedy, 118-127. London: George Allen \& Unwin.

Hechter, M. (1971). Towards a Theory of Ethnic Change. Politics and Society 2: 21-45.

Hornberger, N. H. (1988). Language Planning Orientations and Bilingual Education in Peru. Language Problems and Language Planning 12: 1 (Spring), 14-29.

Hu, G.W. (2001) English Language Teaching in the People's Republic of China. Country report for the Six-Nation Education Research Project on Pedagogical Practices in English Language Education. National Institute of Education, Nanyang Technological University.

Hu, G.W., and L. Alsagoff. 2010. A public policy perspective on English medium instruction in China. Journal of Multilingual and Multicultural Development 31: 365_82.

Jacob, J. E. \& Gordon, D. C. (!985). Language Policy in France'. In Language Policy and National Unity, eds. Beer \& Jacob, 106-133. New Jersey, Totowa: Rowsman \& Allanhead.

Jaspers, J. (2007). In the name of science? On identifying an ethnolect in an Antwerp secondary school (Working Papers in Urban Language and Literacies 42). London: King's College.

Jiang, Y. (2003). English as a Chinese Language. English Today, 19(2), 3-8 
Jørgensen, J.N. (2010). Languaging. Nine years of poly-lingual development of young Turkish-Danish grade school students (Copenhagen Studies in Bilingualism, the Køge Series K15-K16, Vols. 1-2). Copenhagen: University of Copenhagen.

Juffermans, K. (2010). Local languaging. Literacy products and practices in Gambian society. Tilburg: Tilburg University.

Kammi, S. F. (1988). Punjabi Zaban Naheen Mare Gi. Jhelum: Majidia Maktab.

Keim, I. (2007). Die 'tu 'rkischen Powergirls'. Lebenswelt und kommunikativer Stil einer Migrantinnengruppe in Mannheim [The "Turkish Power Girls." Lifeworld and communicative style of an immigrant group in Mannheim]. Tu“bingen: Gunter Narr.

Kennedy, C. (1989). Language Planning and English Language Teaching. Hertfordshire: Prentice-Hall International.

Kloss, H. (1969). Research Possibilities on Group Bilingualism: A Report. Quebec: International Centre for Research on Bilingualism.

Laitin, D. D. (1988). Language Policy and Political Strategy in India. Policy Sciences 22, 415436.

Le page, R. B. (1964). The National Language Question. London: Oxford University Press.

Lee,W.O. (1996) The cultural context for Chinese learners: Conceptions of learning in the Confucian tradition. InD.A.Watkins and J.B. Biggs (eds) The Chinese Learner: Cultural, Psychological and Contextual Influences (pp. 25-41). Hong Kong: CERC and ACER.

Li, X.J. (1984). In defence of the communicative approach. ELT Journal 38, 2-13.

Llasera, I. (1987) Confucian education through European eyes. In R. Hayhoe and M. Bastid (eds) China's Education and the IndustrializedWorld: Studies in Cultural Transfer (pp. 21-32). New York: M.E. Sharpe.

Meganathan, R. (2011). Language policy in education and the role of English in India: From library language to language of empowerment. Retrieved from, www.britishcounci.org

Ministry of Education. (1966). 'Education Commission "Kothari Commission”. 1964-1966. Education and National Development. Ministry of Education, Government of India.

National Education Policy. (August 01, 2009). Ministry of Education and Government of Pakistan.

Noss, R. (1967). Language Policy and Higher Education. Vol. 3. Paris: UNESCO and the International Association of Universities.

Palome, E. C. (1968). 'The Choice of Official Languages in Democratic Republic of Congo'. In Language Problems of Developing Countries Nations, eds. Joshua A Fishman.et al, 295-311. New York: John Wiley.

Pakistan Beureau of Statistics. (2001). Pakistan Demographic Survey. PBS. Retreived from http://www.pbs.gov.pk/content/pakistan-demographic-survey-2001

Pakistan's Legislative History. (2015). The Constitution of Islamic Republic of Pakistan.

Retreived from, http://www.pakistani.org/pakistan/constitution/ 
Punjab Education and English Language Initiative Project. (2013). PEELI Report. British Council. Retreived from, www.britishcouncil.org.pk

Punjab School Education Board Calendar. Vol.II. (2002). Academic Regulations. SAS Nagar: Mohali Publishers.

Rahman, T. (1996). Language and Polities in Pakistan Karachi: Oxford University Press.

Rahman, T. (2002) Language, Ideology and Power, Language Learning Among the Muslims of Pakistan and North India Karachi: Oxford University Press.

Rao, Z.H. (1996) Reconciling communicative approaches to the teaching of English with traditional Chinese methods. Research in the Teaching of English 30, 458-471.

NORRIC Report. (2006). Report on the Education system in Pakistan. Nordic Recognition Information Centres. Retreived from, www.norric.org

Ross, H. A. (1993). China Learns English: Language Teaching and Social change in the People's Republic. New Haven, CT: Yale University Press.

Rudnyckyj, J. B. (1976). Linguicide. Winnipeg: Ukrainian Technical University.

Scollon, S. (1999)Not to waste words or students: Confucian and Socratic discourse in the tertiary classroom. In E. Hinkel (ed.) Culture in Second Language Teaching and Learning (pp. 13-27). Cambridge: Cambridge University Press.

Todd, L. (1961). Language Options for Education in a Multi-Lingual Society Cameroon. In Language Planning and Language Education, ed. Chris Kennedy, 160-171. London: George Allen \& Unwin.

Wardaugh, Ronald. (1987). Languages in Competition: Dominance, Diversity and Decline. Oxford: Basil Blackwell in association with Andre' Deutch.

Wang, M.J. (2001) The cultural characteristics of Chinese students: A study of basic attitudes and approaches to their English studies. RELC Journal 32 (1), 16-33.

Widdowson, H.G. (1990) Aspects of Language Teaching. Oxford: Oxford University Press.

Weinstein, Brian. 'Language Planning in Francophone Africa'. Language Problems and Language Planning 4 (1): 55-77, 1980.

Zhao, Y. \& Campbell, K. P. (1995). English in China. World Englishes, 14(3), 370-390. 
